\title{
Propionibacteria as a cause of shunt and postneurosurgical infections
}

\author{
P. R. SKINNER, A. J. TAYLOR ${ }^{1}$, AND H. COAKHAM ${ }^{2}$ \\ From the Clinical Laboratories, Maudsley Hospital, London; ${ }^{1}$ the Bacterial Metabolism Research \\ Laboratory, Central Public Health Laboratory, London; and ${ }^{2}$ the Neurosurgical Unit, Maudsley Hospital, \\ London
}

SUMMARY Propionibacterium acnes was isolated from postoperative specimens from nine neurosurgical patients. The role of $P$. acnes in postneurosurgical infection is discussed.

Propionibacterium species are Gram-positive, nonmotile, non spore-bearing bacilli, usually pleomorphic, diphtheroid, or club-shaped with one end rounded and the other end tapered or pointed and staining less intensely. Cells may be coccoid, elongate, or even branched (Buchanan and Gibbons, 1974). Growth is anaerobic or aerotolerant, no growth occurring at atmospheric levels of oxygen. Eight species of Propionibacterium are recognised with $P$. freudenreichii as the type species.

Propionibacterium (Corynebacterium) acnes is a major member of the skin flora and is probably the dominant bacterium of sebaceous areas (Ray and Kellum, 1970). Evans (1975) found propionibacteria on the skin of the forehead in 44 out of 48 subjects in numbers up to $1 \cdot 1 \times 10^{6}$ per $\mathrm{cm}^{2}$.

$P$. acnes has been incriminated in the pathogenesis of acne in man. Leyden et al. (1975) studied carriage in three groups of subjects and found propionibacteria to be present in the skin of a pubertal group only in those with acne. In contrast in patients over 21 years old, carriage did not vary between acne and non-acne groups. One theory of the role of $P$. acnes is that bacterial esterases release fatty acids by hydrolysis of triglycerides, and these acids produce a primary irritant dermatitis of the wall of sebaceous follicles (Kellum et al., 1970).

Reports in the literature incriminating $P$. acnes as a potential human pathogen and the known carriage of the organism in the region of neurosurgical operation sites led to a search for $\boldsymbol{P}$. acnes in clinical specimens of neurosurgical origin. This paper

${ }^{2}$ Present address: The Neurosurgical Research Laboratory, Massachusetts General Hospital, Boston, Mass, USA.

Received for publication 29 March 1978 presents nine cases of post-surgical and shunt infection from which $P$. acnes was isolated.

\section{Material and methods}

SPECIMEN COLLECTION

Specimens were obtained from patients undergoing neurosurgery. Preoperative treatment involved shaving of the head area and swabbing with $0.5 \%$ chlorhexidine in $95 \%$ ethanol $/ 5 \%$ methanol. This was left in contact with the skin for three to five minutes before the operation. The specimens received included scalp flap fluids, wound aspirates, shunts, and ventricular and lumbar spinal fluids.

\section{BACTERIOLOGICAL INVESTIGATIONS}

On fluid specimens, other than blood, a cell count was done on the uncentrifuged specimen. From centrifuged deposits differential cell counts were made on smears stained by Leishman's stain. When fluids were viscous an assessment of cell number was made on films of uncentrifuged specimens and reported as,,++++++ , or \pm . Protein was estimated by the sulphosalicylic acid technique of Meulemans (1960) and sugar by the glucose oxidase technique (Trinder, 1969). The centrifuged deposit was cultured on 5\% horse-blood agar (lab M) incubated aerobically and anaerobically (Gas Pak), chocolate agar incubated in $10 \% \mathrm{CO}_{2}$, and MacConkey agar (lab M). All plates were incubated for 72 hours at $35^{\circ} \mathrm{C}$ and subcultured aerobically and anaerobically at intervals of one, two, and three days, and one, two, and four weeks or whenever visible growth was apparent. Subcultures were incubated for five days at $35^{\circ} \mathrm{C}$. Shunts were placed directly into thioglycollate broth and subcultured as previously described. 
IDENTIFICATION OF ISOLATES

Presumptive identification of all anaerobic bacterial isolates was based on Gram-stain appearance and biochemical reactions in the API 20A system (API Ltd, Rayleigh, Essex). Confirmation of identity was obtained by detection of the end products of glucose metabolism and by biochemical reactions as described by Holdeman and Moore (1972). Cultures were grown in $5 \mathrm{ml}$ of glucose broth $(1 \%$ glucose, $1 \%$ Oxoid peptone, $1 \%$ yeast extract, $0.5 \mu \mathrm{g} / \mathrm{ml}$ menadione, $50 \mu \mathrm{g} / \mathrm{ml}$ haemin) incubated for a minimum of five days at $35^{\circ} \mathrm{C}$. The broth was acidified with $0.1 \mathrm{ml}$ of $50 \%$ sulphuric acid and transferred to chromatography sample bottles for analysis in a Perkin Elmer F.40 multifract automatic gas chromatograph designed for head-space analysis. Sample bottles were placed in a waterbath for 10 minutes at $96^{\circ} \mathrm{C}$ to equilibrate. The machine automatically sampled and analysed the vapour phase of each vial.

The chromatograph was fitted with a flameionisation detector and a 2-metre stainless steel column packed with $15 \%$ carbowax $20 \mathrm{~m}$ and $2 \%$ phosphoric acid on chromosorb W, 80-100 mesh (prepared column No. BS 1386S part No. 498-1222 Perkin Elmer). The carrier gas was oxygen-free nitrogen (BOC) passing at $30 \mathrm{ml} / \mathrm{min}$. The columnoven temperature was $135^{\circ} \mathrm{C}$ and the detector oven was at $200^{\circ} \mathrm{C}$. A four-second injection period was used.

\section{Results}

Clinical data from nine patients from whom 15 isolates of $\boldsymbol{P}$. acnes were made are listed in Table 1 , and the laboratory findings on the specimens are given in Table 2 . The biochemical characteristics of the $P$. acnes isolates are shown in Table 3.

Detailed histories are presented from cases 7,8 , and 9. These cases were selected as being the most characteristic of suspected $P$. acnes infection in post-neurosurgical patients.

\section{CASE 7}

An 11-year-old boy had a right occipital lobectomy for an unusual epileptogenic lesion subsequently reported as chronic encephalitis. On the third postoperative day he developed a fever which persisted at about $39.5^{\circ} \mathrm{C}$ for the next 11 days, during which time he remained alert but irritable with occasional neck stiffness. Physical examination and repeated bacteriological studies of blood, urine, and stool failed to reveal a systemic cause for the pyrexia. A diagnosis of meningitis was made. His peripheral white cell count was $11800 / \mathrm{mm}^{3}\left(11.8 \times 10^{9} / \mathrm{l}\right)$ (85\% polymorphs, $13 \%$ lymphocytes). The lumbar CSF white-cell count was $2000 / \mathrm{mm}^{3}\left(2.0 \times 10^{9} / 1\right)$ (90\% polymorphs, $8 \%$ lymphocytes) with a protein of $2750 \mathrm{mg} /$ litre and a sugar of $3.9 \mathrm{mmol} / \mathrm{litre}$. Micro-organisms were not seen in a Gram stained smear but culture yielded $P$. acnes. Gentamicin and chloramphenicol were added to the ampicillin thas had been started at the time of operation, and by the 16th postoperative day he became afebrile.

\section{CASE 8}

A 46-year-old woman with aqueduct stenosis had had a ventriculoatrial shunt performed in another hospital one year before referral. Staphylococcus epidermidis was found in blood cultures, and the

Table 1 Clinical details of cases from whom propionibacterium was isolated

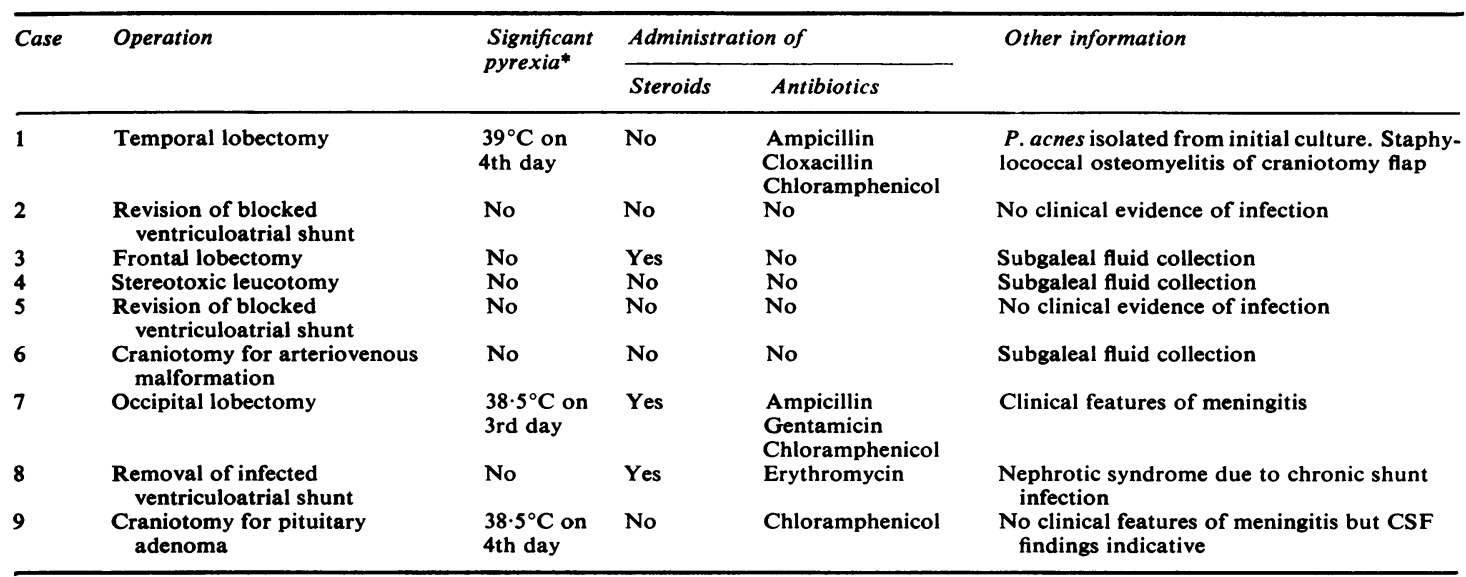

* Low-grade pyrexia in first $\mathbf{2 4}$ hours postoperatively was not considered significant. 
Table 2 Laboratory data from patients with propionibacterial infections

\begin{tabular}{|c|c|c|c|c|}
\hline \multicolumn{2}{|r|}{ Case and date of specimen } & \multirow{2}{*}{$\begin{array}{l}\text { Peripheral WBC count (total per } \mathrm{mm}^{3} \text { ) } \\
\text { Total } 13100 \\
\text { Polys } 88 \% \text {, lymphs } 9 \% \text {, monos } 3 \% \\
\text { Left shift }\end{array}$} & \multirow{2}{*}{$\begin{array}{l}\text { Fluid findings (total cell count/mms) } \\
\text { Cells WBC }+ \\
\text { Polys predominated. } \\
\text { Diff. not done }\end{array}$} & \multirow{2}{*}{$\frac{\text { Gram smear }}{\text { MNS }}$} \\
\hline 1 & $\begin{array}{l}26 \text { Oct. ' } 76 \\
\text { Lobectomy cavity fluid }\end{array}$ & & & \\
\hline 2 & $\begin{array}{l}7 \text { Mar. '77 } \\
\text { Shunt tubing }\end{array}$ & $\begin{array}{l}\text { Total } 10200 \\
\text { Polys } 75 \% \text {, lymphs } 15 \% \text {, monos } 10 \%\end{array}$ & & Not done \\
\hline 3 & $\begin{array}{l}31 \text { Jan. '77 } \\
\text { Subgaleal fluid }\end{array}$ & $\begin{array}{l}\text { Total } 1800 \\
\text { Polys } 77 \% \text {, lymphs } 20 \% \text {, monos } 3 \% \\
\text { Left shift. Toxic granulation }\end{array}$ & $\begin{array}{l}\text { Cells WBC }+++ \\
\text { Polys } 90 \% \\
\text { Lymphs } 2 \% \\
\text { Monos } 8 \%\end{array}$ & MNS \\
\hline & $\begin{array}{l}1 \text { Jan. '77 } \\
\text { Subgaleal fluid }\end{array}$ & Not done & $\begin{array}{l}\text { Cells WBC }++ \\
\text { Polys } 98 \% \\
\text { Monos } 2 \%\end{array}$ & MNS \\
\hline 4 & $\begin{array}{l}16 \text { June ' } 77 \\
\text { Wound aspirate }\end{array}$ & Not done & $\begin{array}{l}\text { Cells WBC }++ \\
\text { Polys } 97 \% \\
\text { Monos } 3 \%\end{array}$ & $\begin{array}{l}\text { Gram + ve } \\
\text { cocco- } \\
\text { bacilli } \pm\end{array}$ \\
\hline 5 & $\begin{array}{l}27 \text { May ‘ } 77 \\
\text { Ventricular CSF }\end{array}$ & $\begin{array}{l}\text { Total } 8100 \\
\text { Polys } 58 \% \text {, lymphs } 38 \% \text {, monos } 4 \%\end{array}$ & $\begin{array}{l}\text { RBC } 100 \\
\text { WBC none } \\
\text { Protein QNS } \\
\text { Sugar } 0.9 \mathrm{mmol} / 1\end{array}$ & MNS \\
\hline 6 & $\begin{array}{l}31 \text { Dec. '76 } \\
\text { Subgaleal fluid }\end{array}$ & $\begin{array}{l}\text { Total } 23000 \\
\text { Polys } 87 \% \text {, lymphs } 10 \% \text {, monos } 3 \% \\
\text { Left shift }\end{array}$ & $\begin{array}{l}\text { Cells WBC + } \\
\text { Polys } 89 \% \\
\text { Lymphs } 49 \% \\
\text { Monos } 7 \%\end{array}$ & MNS \\
\hline & $\begin{array}{l}13 \text { Jan. '77 } \\
\text { Flap fluid }\end{array}$ & $\begin{array}{l}\text { Total } 13800 \\
\text { Polys } 67 \% \text {, lymphs } 29 \% \text {, monos } 4 \%\end{array}$ & $\begin{array}{l}\text { Cells WBC }+++ \\
\text { Polys } 64 \% \\
\text { Lymphs } 25 \% \\
\text { Monos } 11 \%\end{array}$ & $\begin{array}{l}\text { Gram }+ \text { ve } \\
\text { bacilli }+\end{array}$ \\
\hline 7 & $\begin{array}{l}28 \text { May '77 } \\
\text { CSF lumbar }\end{array}$ & $\begin{array}{l}\text { Total } 11800 \\
\text { Polys } 85 \% \text {, lymphs } 13 \% \text {, monos } 2 \%\end{array}$ & $\begin{array}{l}\text { WBC } 2000 \\
\text { Polys } 90 \% \\
\text { Lymphs } 8 \% \\
\text { Monos } 2 \% \\
\text { Protein } 2750 \mathrm{mg} / 1 \\
\text { Sugar } 3.9 \mathrm{mmol} / 1\end{array}$ & MNS \\
\hline 8 & $\begin{array}{l}20 \text { Dec. '76 } \\
\text { CSF ventricular }\end{array}$ & $\begin{array}{l}\text { Total } 14000 \\
\text { Polys } 86 \% \text {, lymphs } 14 \%\end{array}$ & $\begin{array}{l}\text { RBC } 3020 \text { WBC } 196 \\
\text { Polys } 60 \% \\
\text { Lymphs } 20 \% \\
\text { Monos } 20 \% \\
\text { Protein } 660 \mathrm{mg} / 1 \\
\text { Sugar } 4.2 \mathrm{mmol} / 1\end{array}$ & $\begin{array}{l}\text { Gram +ve } \\
\text { bacilli }+\end{array}$ \\
\hline & $\begin{array}{l}21 \text { Dec. } 76 \\
\text { CSF ventricular }\end{array}$ & $\begin{array}{l}\text { Total } 8800 \\
\text { Polys } 78 \% \text {, lymphs } 22 \%\end{array}$ & $\begin{array}{l}\text { RBC } 800 \text { WBC } 95 \\
\text { Polys } 82 \% \\
\text { Lymphs } 10 \% \\
\text { Monos } 8 \% \\
\text { Protein } 330 \mathrm{mg} / 1 \\
\text { Sugar } 4.1 \mathrm{mmol} / 1\end{array}$ & $\begin{array}{l}\text { Gram }+ \text { ve } \\
\text { bacilli }+\end{array}$ \\
\hline & $\begin{array}{l}22 \text { Dec. '76 } \\
\text { CSF ventricular }\end{array}$ & Not done & $\begin{array}{l}\text { RBC } 4800 \text { WBC } 53 \\
\text { Polys } 70 \% \\
\text { Lymphs } 18 \% \\
\text { Monos } 12 \% \\
\text { Protein } 275 \mathrm{mg} / 1 \\
\text { Sugar } 4.1 \mathrm{mmol} / 1\end{array}$ & MNS \\
\hline 9 & $\begin{array}{l}21 \text { Apr. ' } 77 \\
\text { CSF xanthochromic }\end{array}$ & $\begin{array}{l}\text { Total } 13700 \\
\text { Polys } 77 \% \text {, lymphs } 17 \% \text {, monos } 5 \% \text {, Eosin } 1 \% \\
\text { Left shift }\end{array}$ & $\begin{array}{l}\text { RBC } 6000 \text { WBC } 800 \\
\text { Polys } 93 \% \\
\text { Lymphs } 6 \% \\
\text { Monos } 1 \% \\
\text { Protein } 2750 \mathrm{mg} 1 \\
\text { Sugar } 1.6 \mathrm{mmol} / 1\end{array}$ & MNS \\
\hline
\end{tabular}

MNS = microorganisms not seen; QNS = quantity not sufficient

atrial shunt?was changed. She subsequently developed a nephrotic syndrome presumed to be due to the persistence of the Staph. epidermidis in the shunt, and the microorganism was again isolated from the blood. Preoperative erythromycin (appropriate to sensitivity) was given, and the entire shunt system was removed with insertion of external ventricular drainage. The removed shunt grew Staph. epidermidis.
The ventricular fluid showed RBC $3020 / \mathrm{mm}^{3}$ $\left(3.0 \times 10^{9} / 1\right)$, WBC $196 / \mathrm{mm}^{3}\left(0.2 \times 10^{9} / 1\right)(60 \%$ polymorphs, $20 \%$ lymphs, $20 \%$ monocytes), sugar $4 \cdot 2$ $\mathrm{mmol} / 1$, and protein $660 \mathrm{mg} / \mathrm{l}$. Gram-positive bacilli were seen and cultures yielded $\boldsymbol{P}$. acnes. Two more ventricular fluid samples obtained during drainage yielded $P$. acnes on culture, and in the first of these samples the microorganisms were again seen on Gram 
Table 3 Biochemical characteristics of $P$. acnes isolates

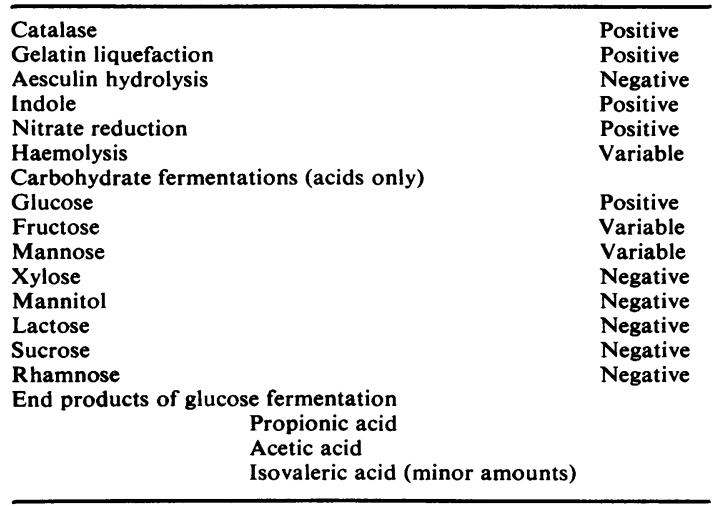

stain. A new ventriculoperitoneal shunt was subsequently put in.

CASE 9

A 44-year-old man became febrile (up to $38.5^{\circ} \mathrm{C}$ ) on the fourth postoperative day after craniotomy for pituitary adenoma. There was no clinical evidence of chest or wound infection, and blood and urine cultures were sterile. Meningitis was therefore suspected. On the sixth day lumbar CSF was examined and found to contain $6000 \mathrm{WBC} / \mathrm{mm}^{3}\left(6.0 \times 10^{9} / \mathrm{l}\right)$ (93\% polymorphs, 6\% lymphs, $1 \%$ monocytes), protein $2750 \mathrm{mg} / \mathrm{l}$, and sugar $1.6 \mathrm{mmol} / \mathrm{l}$. P. acnes was isolated from the CSF. The peripheral blood at this time was $13700 \mathrm{WBC} / \mathrm{mm}^{3}\left(13.7 \times 10^{9} / \mathrm{l}\right)$ (77\% polymorphs showing a left shift). Intramuscular chloramphenicol was started and the next day his fever subsided. There had been no neurological deterioration throughout this period.

\section{Discussion}

Propionibacteria have been described as being of little significance and are often disregarded as contaminants when isolated in the microbiology laboratory (Kaplan and Weinstein, 1969). There have, however, been reports incriminating $P$. acnes in a range of infections in man other than acne vulgaris, for example, meningitis (Kimbrell, 1964; Graber et al., 1965), infected cerebrospinal fluid shunts (Everett et al., 1976; Beeler et al., 1976), and wound infections, osteomyelitis, and bacterial endocarditis (Kaplan and Weinstein, 1969).

The isolation of $P$. acnes from these nine cases may be explained in one of three ways. The isolates may be laboratory contaminants or skin commensals, or may genuinely be playing a pathogenic role in some or all of these patients. Culture of $P$. acnes in pure culture from 15 specimens submitted from nine patients over a period of six months makes laboratory contamination unlikely because most of the similar specimens from asymptomatic patients remained sterile. Simple culture of skin bacteria is also unlikely because $P$. acnes, although a dominant member of the skin flora, particularly on the head, is rarely the only species present, and many other common skin bacteria are far easier to grow in the laboratory than are propionibacteria. The case for $P$. acnes being a significant isolate rests upon the data in Tables 1 and 2.

Pyrexia was noted in three of the nine cases. There was a correlation between pyrexia and peripheral blood leucocytosis and neutrophilia in all three cases. Leucocytosis with neutrophilia is a common finding postoperatively, with tissue damage and general trauma, resulting in the redistribution of the neutrophils between the marginal and circulating neutrophil pools. The normal duration of this response is 12 to 30 hours (Wintrobe, 1975). Of all the cases with neutrophilia, only case 9 returned to within normal limits in less than four days. Pyrexia may not be a relevant feature of $P$. acnes infestion; Schlesinger and Ross (1977) noted that in de novo diphtheroid meningitis focal signs of cerebral dysfunction preceded the afebrile course of the disease, microorganisms being occasionally seen in Gram-stained films. The picture in CSF was one of an aseptic meningitis with a mononuclear leucocytosis and normal levels of glucose. Pyrexia may not, therefore, be a relevant criterion for infection. The CSF glucose levels in our series of patients varied from case to case, and the predominant cellular response was neutrophilic. In the neurosurgical context the features noted by Schlesinger and Ross (1977) may not apply.In all cases except case 6, the CSF showed a leucocytosis; this may represent a leptomeningeal reaction to infiltration of blood into the fluid. Phagocytic activity provoked by the red blood cells is manifested by the macrophages, and these phagocytes may be seen with ingested red blood cells either as intact cells or as vacuoles in the cytoplasm. The macrophages may be present for several months after the initial bleed (Kölmel, 1977). However, none of these cellular elements was seen in the specimens examined.

Cases of propionibacterial infection previously reported have involved mainly meningitis or infected CSF shunts. In nearly all cases the patients had some predisposing illness or had undergone operation which had increased the likelihood of infection. In all nine cases described in this study the patients had, for a variety of causes, had a neurological operation that involved incision through areas of skin known to be heavily 
colonised with this type of microorganism (Evans, 1975). As a skin disinfectant $0.5 \%$ chlorhexidine has been shown to be effective (Nielsen et al., 1975). Repeated Sellotape swabbing of the foreheads of volunteers known to carry $\boldsymbol{P}$. acnes failed to yield that organism after standard treatment with $0.5 \%$ chlorhexidine. The skin surface appears to be cleared of organisms but results of a survey now in progress, which involves freshly cut scalp tissue, suggest that $\boldsymbol{P}$. acnes living in the sebaceous glands (Woodroofe and Shaw, 1974) may survive the skin preparation and be released on incision.

The spectrum of $P$. acnes involvement includes its presence in subgaleal effusions (cases $3,4,6$ ). These arise from mechanical complications and were resolved without antibiotics. The presence of $P$. acnes in such effusions may be relatively insignificant, but a survey of a large series of scalp flap collections has been instituted.

$P$. acnes was isolated from shunt cases 2,5 , and 8 . In two of these cases ( 2 and 5 ) operation was for blockage of shunt without clinical evidence of infection and with negative blood cultures.P.acnes was cultured from the tubing of both cases and from the ventricular CSF of one (case 6). These patients represent the occult shunt colonisation of the type described by Fokes (1970). The third case was diagnosed as chronic Staph. epidermidis septicaemia by preoperative blood cultures at another hospital. However, the presence of $\boldsymbol{P}$. acnes in Gram-stained ventricular CSF at the time of shunt removal suggests that this microorganism was well established. $P$. acnes has been reported previously as the sole cause of immune-complex glomerular nephritis in chronic shunt infection (Beeler et al., 1976).

In case $1 P$. acnes was cultured from the first needle aspirate of the lobectomy cavity on the fourth day postoperatively when the patient had fever, headache, and haematological indications of infection. This was followed on the seventh postoperative day by a Staph. aureus osteomyelitis, which necessitated bone flap removal and vigorous antibiotic therapy. The meningeal symptoms were associated with the $P$. acnes isolation and Staph. aureus followed, causing necrosis of the bone flap.

The range of possible infection is completed by the two postoperative meningitis cases 7 and 9 . Both cases developed fever, with CSF polymorph leucocytosis and raised protein. Case 7 had mild meningitic symptoms while case 9 was neurologically unchanged yet had significant depression of CSF sugar $(1.6 \mathrm{mmol} / \mathrm{l})$. $P$. acnes cannot be implicated with certainty as the primary aetiological agent, but this possibility is highly likely since no other microorganisms were isolated and there was a response to antibiotics.
All the propionibacteria isolated in this study were sensitive by disc diffusion testing to tetracycline, carbenicillin, penicillin, clindamycin, chloramphenicol, and erythromycin but were resistant to metronidazole with MICs, determined by the agar dilution method, of $>100 \mathrm{mg} / \mathrm{l}$. This correlates with the findings of Wüst (1977) and Henderson et al. (1977) that propionibacteria and Actinomyces sp are the only clinically important groups of anaerobes resistant to the nitroimadazole group of antimicrobial agents.

The isolation of $P$. acnes in pure culture correlated with the haematological and CSF findings, and the benign indolent nature of the cases of postoperative meningitis suggests $P$. acnes as the aetiological agent (Schlesinger and Ross, 1977). Postoperative meningitis associated with $P$. acnes has not been reported before, and it is clearly important to study prospectively a larger series of neurosurgical cases in which a 'sterile' meningitis occurs. Demonstration of circulating antibodies against the patient's organism (French et al., 1974; Beeler et al., 1976) and CSF LDH (Beaty and Oppenheimer, 1968) and IgA (Sheth, 1971) levels would provide futher evidence of a genuine role for this group of microorganisms as a significant pathogen in some types of patient.

We are grateful to Mr P. H. Schurr, Mr C. E. Polkey, and $\mathrm{Mr}$ J. J. MacCabe for permission to publish these cases, and to Dr M. Carruthers and Dr M. J. Hill for helpful advice and encouragement.

\section{References}

Beaty, H. N., and Oppenheimer, S. (1968). Cerebrospinalfluid lactic dehydrogenase and its isoenzymes in infections of the central nervous system. New England Journal of Medicine, 279, 1197-1202.

Beeler, B. A., Crowder, J. G., Smith, J. W., and White, A. (1976). Propionibacterium acnes: pathogen in central nervous system shunt infection. American Journal of Medicine, 61, 935-938.

Buchanan, R. E., and Gibbons, N. E. (Editors) (1974). Bergey's Manual of Determinative Bacteriology, 8th edition. Williams and Wilkins, Baltimore.

Evans, C. A. (1975). Persistent individual differences in the bacterial flora of the skin of the forehead; Numbers of propionibacteria. Journal of Investigative Dermatology, 64, 42-46.

Everett, E. D., Eickhoff, T. C., and Simon, R. H. (1976). Cerebrospinal fluid shunt infections with anaerobic diphtheroids (Propionibacterium species). Journal of Neurosurgery, 44, 580-584.

Fokes, E. C., Jr. (1970). Occult infections of ventriculoatrial shunts. Journal of Neurosurgery, 33, 517-523.

French, R. S., Ziter, F. A., Spruance, S. L., and Smith, 
C. B. (1974). Chronic meningitis caused by Propionibacterium acnes. Neurology, 24, 624-628.

Graber, C. D., Higgins, L. S., and Davis, J. S. (1965). Seldom-encountered agents of bacterial meningitis. Journal of the American Medical Association, 192, 956-960.

Henderson, D. K., Chow, A. W., and Guze, L. B. (1977). Comparative susceptibility of anaerobic bacteria to ticarcillin, cefoxitin, metronidazole and related antimicrobial agents. Antimicrobial Agents and Chemotherapy, 11, 679-682.

Holdeman, L. V., and Moore, W. E. C. (1972). Anaerobic Laboratory Manual. Virginia Polytechnic Institute, USA.

Kaplan, K., and Weinstein, L. (1969). Diphtheroid infections of Man. Annals of Internal Medicine, 70, 919-929.

Kellum, R. E., Strangfeld, K., and Ray, L. F. (1970). Acne vulgaris studies in pathogenesis: Triglyceride hydrolysis by Corynebacterium acnes in vitro. Archives of Dermatology, 101, 41-47.

Kimbrell, O. C., Jr. (1964). Corynebacterium acnesA cause of meningitis. North Carolina Medical Journal, 25, 516-519.

Kölmel, H. W. (1977). Atlas of Cerebrospinal Fluid Cells, 2nd edition. Springer, Berlin.

Leyden, J. L., McGinley, K. J., Mills, O. H., and Kligman, A. M. (1975). Propionibacterium levels in patients with and without acne vulgaris. Journal of Investigative Dermatology, 65, 382-384.

Meulemans, O. (1960). Determination of total protein in spinal fluid with sulphosalicylic acid and trichloro- acetic acid. Clinica Chimica Acta, 5, 757-761.

Neilsen, M. L., Raahave, D., Stage, J. G., and Justesen, T. (1975). Anaerobic and aerobic skin bacteria before and after skin-disinfection with chlorhexidine. An experimental study in volunteers. Journal of Clinical Pathology, 28, 793-797.

Ray, L. F., and Kellum, R. E. (1970). Corynebacterium acnes from human skin. Archives of Dermatology, 101, 36-40.

Schlesinger, J. J., and Ross, A. L. (1977). Propionibacterium acnes meningitis in a previously normal adult. Archives of Internal Medicine, 137, 921-923.

Sheth, N. K. (1971). The possible significance of IgA in abnormal cerebrospinal fluid. Journal of Clinical Pathology, 24, 363-365.

Trinder, P. (1969). Determination of blood glucose using an oxidase-peroxidase system with a non-carcinogenic chromogen. Journal of Clinical Pathology, 22, 158-161.

Wintrobe, M. M. (1975). Clinical Haematology, 7th edition, Kimpton, London.

Woodroffe, R. C. S., and Shaw, D. A. (1974). Natural Control and Ecology of Microbial Population of Skin and Hair in the Normal Flora of Man. Academic Press, London and New York.

Wüst, J. (1977). Susceptibility of anaerobic bacteria to metronidazole, ornidazole, and tinidazole and routine susceptibility testing by standardized methods. Antimicrobial Agents and Chemotherapy, 11, 631-637.

Requests for reprints to: A. J. Taylor, Bacterial Metabolism Research Laboratory, Central Public Health Laboratory, Colindale Avenue, London NW9 5HT. 